\title{
The African Union Continental Free Trade Area: Challenges and Prospects
}

\author{
Nwaodu Nnamdi Okechukwu, Ijeoma Edwin Okechukwu Chikata \\ Department of Public Administration, University of Fort Hare, Alice, South Africa \\ Email address: \\ nwaodunnamdi@yahoo.com (N. N. Okechukwu)
}

\section{To cite this article:}

Nwaodu Nnamdi Okechukwu, Ijeoma Edwin Okechukwu Chikata. The African Union Continental Free Trade Area: Challenges and Prospects. International Journal of Sustainable Development Research. Vol. 4, No. 2, 2018, pp. 36-43. doi: 10.11648/j.ijsdr.20180402.14

Received: December 11, 2017; Accepted: April 8, 2018; Published: September 27, 2018

\begin{abstract}
One of the bitter legacies of colonialism in Africa is the creation of small unit states which reduced the singular and collective competitiveness of the states and the continent respectively in global economic and political affairs. It has therefore been the resolve of African leaders to pursue some forms regional integration in order to overcome the challenges. Consequently, from the pre-independence pan-Africanist philosophy, to the Organization of African Unity, OAU and today the African Union, this fundamental goal of building integration mechanisms has remained prevalent at the regional and subregional levels, leading to the desire to establish integration schemes for customs' union, economic community, common currency, central bank and one parliament, and most currently that of the Free Trade Area in the Continent. This article sought to unpack some of the challenges of regional integration in general and those facing the AU's continent-wide Free Trade Area and found that, though efforts towards regional integration in Africa have recorded some achievements including positive economic growth, they still fall short of achieving most of its laudable objectives especially in the face of such challenges ranging from over-ambitious targets, to the heterogeneity of the economies of members, among others. For effective regional integration in Africa, AU should basically resolve the identified knotty challenges that have frustrated a possible beneficial intra-regional trade which could subsequently lead to regional integration in Africa without which the drive for collective selfreliant development for Africa will always turn into a mirage, deepening the region's dependence on the western powers.
\end{abstract}

Keywords: Regional Integration, African Union (AU), Free Trade Area

\section{Introduction}

Africa is richly endowed with huge human and natural resources capable of making her the economic and political hub of the world, but, being split among "fifty-four" territories, with her markets as well balkanized into such bits, she remains without basis for large scale industrial complexes. She therefore, remains far from her real potentials as none of the constituent states is thus economically large enough to construct a competitive modern economy alone, providing basis for longstanding drive for an integrated African regional economy or sub-regional economies aimed at protecting the region from the rather suffocating global economic competition.

Today, the African Union (AU) has come to symbolize Africa's vision of building a united and strong African region with a viable partnership between its governments and all the various segments of the civil society especially in this era of globalization and world market integration. She hinges the attainment of her vision on continental and sub-regional cooperation more than on any external agencies as ever before. This strength in collective vision was captured in the words of President Mkapa of Tanzania thus: "what was required and made emphatic is that Africa defines its own economic destiny, strengthen its capacity to design and implement sound economic and development policies". [1]

The AU has defined and tried to implement this economic vision in many instruments and mechanisms, but these her collective economic vision and vision for Africa have not yet brought about the desired continental development and the Continent still remains grossly dependent on the Western technology and capital thereby ultimately deterring same goals it is set to achieve.

This is not to say that the regional development interventions had zero achievements, for there are instances of economic growth and resolution of political crisis in many 
states of the continent such as in Sudan and Ivory Coast, therefore, collective efforts have availed the region of some benefits.

Overall, desired development has eluded Africa even in the face of the numerous African Union's development initiatives and programmes. However, today, the unrelenting African Union is evolving more schemes for achieving continental integration which it holds as key to development of the region. Among such numerous initiatives is the recent Continental Free Trade Area, CFTA which is being orchestrated as mechanism fundamental to achieving industrialisation, economic growth, poverty reduction; enhancing food security, and access to essential services as leeway to the continent's overall sustainable development goals.

Though still evolving, the CFTA is fraught with many challenging situations and circumstances. To that extent, the study is set to identify and assess the challenges and prospects of the CFTA as a development instrument for the AU. It will also assess the propensity of the Agreement in promoting sustainable development at the economic, social and cultural levels as well as integrating the divergent African markets and economies and as well determine constraints to these goals.

\section{Methods of the Research}

The study was executed using qualitative research method in which basically secondary data were collected and analysed and conclusions drawn from the findings.

\section{Conceptual and Theoretical Framework of the Study}

\subsection{Regional Integration}

This is a process of transferring loyalty from national to supranational organization and of increasing interdependence and cooperation between nation-states in a given region. It is a movement away from nationalism towards regionalism or internationalism, a movement away from fragmentation (economic and political) of states and towards supranational unification. It may take various forms; free trade zone which dispenses with trade restrictions: custom union which presupposes a lifting of foreign restrictions and the establishment of a single trade tariff and a single trade policy in relation to other countries within the community. A more complex form of this is the economic union which supplements the custom integration with agreement on custom, economic and currency policy. [1]

\subsection{Regional Integration Strategy}

This is a development strategy which anchors on regional integration schemes. This strategy has caught up the fancy of the third world as a viable development strategy since the end of colonialism following the success of regional integration schemes in Europe like European Economic Community, EEC. It is encouraged by the United Nations among the developing countries, for example the UN came up with the idea and indeed established East African Community, EAC, Economic Commission of West African States, ECOWAS, and others. [2] This underlying philosophy was to enable them to exchange ideas among themselves, learn from mistakes and foster economic relations with necessary concessions and waivers. They could also team up to embark on major projects beyond the scope of a single regional group. This could be referred to as 'South-South' relationship. It also created an opportunity for relationship between the Third World regional groupings and those in the Developed countries, for example between ECOWAS and EEC. This could be termed a 'North-South' relationship. It is observed that many years after adopting this strategy in many parts of the developing world, the much desired impact did not come mainly because the integrating countries are themselves greatly dependent on the capital and technology of the West and mode of relationship between the parties remains unequal to the advantage of the developed world.

\subsection{The Economic Cartel Strategy}

The Economic Cartel Strategy drew its clout from the principle of Comparative Advantage in Balance of Trade between nations. This principle encourages countries that have comparative advantage over the others in production of certain goods and services to produce and export such while importing those items for which they are less endowed. It was in the bid to maximize the advantages accruing from this and to discourage unhealthy competition among a group of producing nations that the cartel, Organisation of Petroleum Exporting Countries, OPEC, was established in September, 1960 in Baghdad by five oil-producing Developing countries (that were richly endowed with the mineral resource, crude oil highly needed by some developed/industrialized countries). This most successful cartel has since its establishment regulated the quantities and pricing of the commodity to be supplied into the world market obviously to the advantage of its member-countries. This success, though not without challenges has sensitized the third world countries to positively consider the adoption of this development strategy at different periods.

\subsection{New International Economic Order}

As against the strategies highlighted above, New International Economic Order refers to a conglomeration of proposals laid at the floor of the United Nations General Assembly in 1974 by the Third World Countries. It was a design calling for a restructuring of the prevalent world order asserting that a new order was necessary in order to achieve their economic development. This proposal which was registered at United Nations Commission on Trade and Development, UNCTAD included demand for the Third World's control of their natural resources, increase of Foreign Aid from the developed economies and a reduction of cost of 
technology. The call also included for reduction of Debts of Developing countries as well as having increased influence in the United Nations and its affiliates worldwide. Though this drive for a New International Economic Order, gave rise to some reasonable measure of relevance achieved by the Third World countries in their participation in the affairs of the United Nations and its Affiliates, attained various levels of increase in Foreign Aid, Reduction, Rescheduling or Cancellation of Foreign debts yet the ultimate goal of development for these countries still eludes the group. Multitude of the perceived benefits to some of the countries and in some areas, these Capital Flows have only been mainly in the short run. [3]

\subsection{Theoretical Foundations of Africa's Free Trade Area}

As a fundamental element of regional integration, Free Trade Zone is integrated around the existing theoretical models, perspectives, foundations and strands of regional integration in the field or broader intellectual world. Theories of regional integration refer to the sum of intellectual interpretations and or assumptions of the processes, targets, and directions explored by states towards achieving collective and joint implementations of economic and political activities for the mutual benefit of the participating states. They describe common interests, bounds or convergences of the states stretching political, economic, security, technology, cultural realms and more. They mainly focus on exploring how all the members of a regional community could maximize inherent benefits in economic and political community, and determine the most appropriate ways for the redistribution of the benefits. In other words, they ordinarily seek to explain what, why, and how the convergence of states would produce the most beneficial outcome for the parties.

Theoretical discussion related to integration had taken deep root since the post-World War 11 and have continued to increase in number and scope till date especially in relation to the European integration. Among these theories are; transnationalism, federalism, intergovernmentalism, functionalism / neo-functionalism, realism and neorealism among others but neo-functionalism best explains the basic framework for this paper.

A founding father of neo-functionalism, Ernst Haas, took as his starting-point a criticism of David Mittrany's functionalism from the 1940s. He basically combined functionalism with inspiration from Jean Monnet's pragmatic approach to European integration but contrary to the functionalists, Haas and his followers considered regional integration, not universal, or political, or merely functional or technocratic, but his original background conditions for regional integration were that the entities should possess pluralistic social structures, be substantially economic and industrially developed, and there should be a common ideological pattern among participating units [4 p484-485]. In other words, his analysis was limited to explaining integration in pluralistic democracies.

Neo-functionalism's intellectual roots therefore lie in functionalism, and do not consider a state to be a relevant actor in the integration process. Instead, its main argument is that a transnational logic and a functional way of organizing human activity were replacing the nation-state. In other words, it was among the first integration theories that tended to circumvent the state almost completely or at least saw that it had very little relevance in steering the process.

The theory itself came to prominence during the 1960s as most of the early works around it also date back to that time. It is a clear departure from trans nationalism, federalism and functionalism, and this makes it clearly a distinct and independent theoretical entity.

\subsection{The Spill-over Hypothesis}

This neo-functionalist hypothesis underscores integration as a linear and progressive phenomenon given that, as nations engage in the integration processes, there arise automatically a functional spill-over from lower to higher levels and from limited to wider scope in a chain of processes. It hinges on the European experience rooting from the ECSC as the starting point to the EEC and to the present EU. In this sense, it was an attempt to attach a theoretical angle to the thinking of the founders of the ECSC.

As relates to the AU's Free Trade Area, it lays foundation for higher level integration in the African region. Mapuva and Muyengwa-Mapuva [5] remarked that, gradually more endogenous reasons for integration emerge as the process continues, and in this case, the $\mathrm{AU}$ and its numerous institutions provide basic structures that can prosper integration in the continent once the political will among the leadership of member countries are guaranteed. Therefore, embracing the idea of free trade area in the region would gradually spill to other areas of integration such as economic and monetary union as has been envisioned by the AU despite the enormous hurdles on the way.

\subsection{Evolution of Modern Form of Regional Integration}

Events leading the World Wars and the overall impact of the wars on national and international economies especially as regards the countries of Europe brought about a rethink in the Post-World War II as to what future economic and political systems would guarantee peace and prosperity of Europe. European economic and political unity came to prime consideration among political leaders and philosophers. In all, however, an absolute abrogation of national sovereignty was a difficult thing to imagine. Efforts therefore came to be focused on the functionalist approach to integration as expressed in Jean Monnet's Schumann Plan which guiding idea was that war between France and Germany must never again disrupt the politics and prosperity in Europe. Italy and three Benelux states joined in the negotiation that followed and European Coal and Steel Community, ECSC Treaty of Paris, signed $18^{\text {th }}$ April 1951 and implemented from July 1952 among the six European countries. The Treaty laid the foundation for regional integration in Europe and principally sought to integrate the 
coal and steel sectors of the countries in such a way that they could no longer maintain independent capacity to make war on each other. [6p87]

The success of the above early attempt at regional integration motivated the six ECSC members to drive for an expanded integration scheme cutting across economic sectors in Europe and this was achieved through the Rome Treaty of March 1957 which established the EEC and Euratom though it only became effective from $1^{\text {st }}$ January, 1958. The treaty further established a Common Assembly and Court, a Commission and a Council of Ministers for the new communities. Though, the United Kingdom declined to join the Community, the EEC became the rally point for European integration. Through its various policies, the Community established a custom union, common external tariff, and common market. [7]

Over time, the Community also developed its role in external relations through its agreements with former French colonies in the Yaounde Accords of 1963, and Lome Conventions of 1975, 1980, 1985 as well as the Cotonu Partneship Accord of 2000 among others. In November, 1993, the official name of the European Economic Community changed to European Union (the EU) after the ratification of the Maastritcht Treaty by member states' parliaments.

The membership of the EU further expanded from the six to twenty-five, with the accession of the UK, Ireland, and Denmark in 1973, Greece in 1981, Spain and Portugal in 1986, Sweden, Austria, and Finland in 1995, Poland, the Czech Republic, Hungary, Estonia, Latvia, Lithuania, Slovakia, Slovenia, Malta, and Cyprus in 2004 (Mclean and MacMillan, 2003). Today, the EU member states are twenty eight (28) with Croatia joining in 2013.

The Union has as well widened the scope of its regional and defense policies including the Common Foreign and Security Policy, (CFSP) and has successfully adopted the Euro as a single currency for the EU from 1 January, 2002 with as well a European Central Bank [8]. More than anything else, the introduction of the Euro has accelerated the process of market integration in the Europe and beyond.

\section{A Discourse of the AU's Continental Free Trade Area - CFTA}

The African Free Trade Zone is an old idea, having been conceived more than a hundred years ago when in the 1890s, during the colonial era, Cecil Rhodes and other British imperialists envisioned the making of a trade zone spanning the whole African continent from Cape to Cairo. This however was not realized given the conflicting interests of the imperialists in the scramble for Africa and colonialism which further entrenched elements of disintegration in the continent through the imperialists' divide and rule system in different parts of the continent. [9]

The recent AU Agreement establishing Free Trade Area in the African continent is differentiated by the fact that it is the creation of independent African Countries. The present dispensation can be traced historically to numerous initiatives for integration in Africa before and after the time of the OAU formation in May 1963 at Addis Ababa, Ethiopia.

Before this time, the idea of one Africa had been propagated in Africa via the idea and philosophy of PanAfricanism which principally was an African ideological reaction to slavery, racism and colonialism. The Organization for African Unity (OAU) was established to pursue amongst other objectives; ridding the continent of the remaining vestiges of colonization and apartheid, promoting unity and solidarity among African States, coordinating and deifying co-operation for development, safeguarding the sovereignty and territorial integrity of member states and promoting international cooperation within the framework of the United Nations [10], all for the overall development of the continent.

It has been remarked that, the OAU succeeded in ridding Africa of colonialism and apartheid and basically provided an effective medium for effective coordination for common positions on matters of common interest to the continent, for example, "they spoke as one with undivided determination in forging an international consensus in support of the liberation struggle and the fight against apartheid" [11]

Its political ideals notwithstanding, the OAU made early but failed attempts towards a common market in the 1960's and 1970's. However, in the 1980s the Organization made a stride that remains foundational to the present attainment of integration in the region by its adoption of the Lagos Plan of Action (LPA) in Lagos, in April 1980.

The Treaty establishing the African Economic Community (AEC) - 1991: commonly known as the Abuja Treaty, advanced the process as it reaffirmed the commitment of the African leaders to the establishment of an African Economic Community (AEC) by the year 2000 and sought to create the AEC through six stages culminating in an African Common Market using the Regional Economic Communities (RECs) as building blocks. The treaty has been in operation since 1994. This community would foster the economic, social and cultural integration of Africa.

However, in real terms, not much was achieved in the integration of the continent during the period. Observably, Africa then was still weighed down with a population of more than 600 million, bogged down by an external debt of $\$ 359$ billion and this debt appropriated more than 80 percent of its gross domestic Product GDP and 320 percent of the continent's export earnings [1]. Arising from these, between 1980 and 1986 Africa's total per capital income declined to 3.5 percent and the number of available jobs declined by 16 percent annually. This resulted to 22 million unemployed and 95 million underemployed Africans. Again Africa was the only region of the world where the number of people remained unchecked, and was greatly increased at the dawn of the $20^{\text {th }}$ century [1].

The OAU's quest for solution to the continent's numerous problems continued as it pushed for avenues to achieve economic integration including adoption of

1) Africa's Common Position on Africa's External Debt 


\section{Crisis.}

2) The Algiers decision on Unconstitutional Changes of Government (1999) and the Lome Declaration on the framework for an OAU's Response to Unconstitutional Changes (2000)

3) The 2000 Solemn Declaration on the Conference on Security, Stability, Development and Cooperation: established the fundamental principles for the promotion of democracy and good governance in the continent.

The OAU also initiated collective action for the protection of environment, combating international terrorism, as well as fighting the scourge of the HIV/AIDS pandemic, malaria and tuberculosis or dealing with humanitarian issues as refugees and displaced persons, landmines, small and light weapons among others.

Indeed, it was in pursuit of the ideal of economic integration that the OAU transited to African Union. The departure from OAU began with the vision of a United States of Africa which was mooted out by Muammar al - Quaddafi, Libya's former Head of State. The Heads of State and Heads of government of the OAU therefore issued the site Declaration on September 9, 1999, calling for the establishment of an African Union. That declaration was followed by summits at Lome 2000, when the Constitutive Act of the African Union was adopted and at Lusaka in 2001, when the plan for implementation of Union Act was adopted. [11]

The African Union formally came alive at its launch in Durban on July 9, 2002, where it also had the first session of the Assembly of the African Union, while the second session of the Assembly was in Maputo in 2003, and the third session in Addis Ababa on July 6, 2004. The main objectives included:-accelerating the political and socio-economic integration of the continent;promoting and defending African common position on issues, encouraging international cooperation, taking due account of the Charter of the United Nations and Universal Declaration of Human Rights, promoting peace, security, and stability on the continent; promoting democratic principles and institutions, popular participation and good governance; promoting and protecting human and peoples; rights in accordance with the Africa Charter on Human and Peoples' Rights and other relevant human rights' instruments; ensuring that the continent play sits rightful role in the global economy and in international negotiations; promoting sustainable development at the economic, social and cultural levels as well as the integration of African economies; coordinating and harmonizing the policies between the existing and future Regional Economic Communities for the gradual attainment of the objectives of the Union; among numerous others. [11]

In the opinion of Mammo, what the OAU was able to do, it had to do, what was beyond it, had to pass on the African Union [12], and since then the AU has do so many things which indeed the OAU did not contemplate talk less of doing.

Currently, it is in due consideration of the fact that, in a fast globalization process, the major global players are not protective of sectors where especially African countries might feasibly compete. The African region's chances for increased gains are grossly diminished by this unfavorable prevailing state of affairs at the global level. To this extent, regional integration - free trade area- is seen as an alternative to unilateral trade liberalization and that has prompted the $\mathrm{AU}$ in its efforts to establish a free trade area in the African continent.

In pursuit of her long-standing aspiration for a free trade area in the African region, the AU in her18th Ordinary Session of the Assembly of Heads of State and Government, held in Addis Ababa, Ethiopia in January 2012, adopted a decision to establish a Continental Free Trade Area (CFTA) by an indicative date of 2017 .

This current CFTA is driven by the AU's goal of enhancing structural transformation of the continent's economies through diversification which she believes would further open employment opportunities; assist regional markets to gain competitiveness before engaging internationally and compete globally. The CFTA as well targets boosting trade in more diversified and processed products within Africa, thus reducing the dependency on imported products.

In specific terms, the main objectives of the CFTA include: creating a single continental market for goods and services, with free movement of business persons and investments, and thus pave the way for fast-tracking the establishment of the Continental Customs Union and the African Customs' Union; expand intra African trade through better harmonization and coordination of trade liberalization and facilitation regimes and instruments across RECs and across Africa in general; and resolve the challenges of multiple and overlapping memberships and expedite the regional and continental integration processes.

The Agreement is also expected to boost competitiveness at the industry and enterprise level by exploring opportunities for scale production, continental market access and better reallocation of resources.

The creation of the CFTA and the putting into practice of the Action Plan on Boosting Intra-African Trade (BIAT) provide a comprehensive framework to pursue a developmental regionalism strategy. The former is conceived as a time bound project, but BIAT is continuous with concrete targets to double intra-African trade flows from January 2012 and January 2022. [13]

So far, the $\mathrm{AU}$ has taken several initiatives aimed at advancing the process of achieving the targets of the CFTA. Such actions include: the decision to establish a High Level Panel of five eminent persons to champion the fast tracking of the CFTA - 27th AU Assembly, July 2016; decision on the Inauguration of Continental Free Trade Area Negotiations Johannesburg, June 2015; declaration on the Launch of the Negotiations for the Establishment of the Continental Free Trade Area (CFTA) - Johannesburg, June 2015.

Other notable actions in same direction are: the unveiling of the Tripartite Free Trade Area in June 2015 (COMESA, 
EAC and SADC). The view is to inaugurate the Continental Free Trade Area (CFTA) to connect the whole of Africa; Draft Framework, Road Map and Architecture For Fasttracking the Continental Free Trade Area (CFTA), among others. [13]

\section{Challenges to Market Integration / Free Trade in Africa}

In general terms, challenges to market integration in the African region range from such factors as are inherent in the mushrooming of sub-regional integration initiatives all over the region, which has led to a multifaceted overlapping in Regional Economic Communities (RECs). This situation worsens the already existing challenges to market integration in the region. [14]

In a separate analysis of the extant situation, Tadelle [15] alsostressed the points that the multiplicity of membership and lack of clarity in the current sub-regional configuration and weak institutions to implement the region's integration agenda constitute a bottleneck to moving forward with regional integration in Africa. Similarly, Hartzenberg [16] underscores that despite Africa's efforts for integration are characterized by too ambitious targets, records on the ground show poor implementation. For instance, the situation of SADC, EAC and COMESA which are all major blocks have a spaghetti bowel type of sub-regional blocks or unions which their member states are belonging to. EAC is at present a common market, but it shares four member States with COMESA and one Member State with SADC. For SADC the same might be said as well, five of its members are in another sub-regional group called Southern African Customs Union (SACU).

Same challenges are visible in COMESA since it has four of its members who are in ECCAS, two are in SACU, four other members are in IGAD and other two are in IOC. There are also two of COMESA's members are in Nile Basin Initiative which is another subdivision of the region at the time regional integration is viewed as the answer to economic prosperity for Africa. In West Africa, it is same as out of ECOWAS fifteen members seven of are in another sub-regional group called CILSS, ten other members are in WAEMU and other groupings as indicated in the figure below, but all of them are as well in negotiations to create different customs' unions from the one they are already in. Again, COMESA and SADC both have seven member States collectively that are not part of a customs union, but all are arranging a customs unions. So, of the twenty-six countries in COMESA, EAC and SADC, seventeen are either in a customs' union and talking about another customs' union different from the one they are already part of, or are discussing about two distinct customs' unions [17] which makes regional integration in Africa "a pie in the sky" as each of these sub-regional groupings have their own problems.

In specific terms, the prevailing challenges of free trade in
Africa's scattered small markets include the long standing and now increasing marginalization of the region in a world market dominated by powerful trading blocs. In addition, the individual African state's disadvantageous unilateral interaction with some of these power blocs still remain a major concern for her free-trade-driven market integration ambition.

The lingering African countries external dependence on similar export crops traded on intra-regionally still continues. This is a clear contradiction that is inimical to the region's economic goals of a free trade area. It is factual that for Africa to have started integration at a low level of intraregional trade yet has a very high dependence on similar export crops indicates lack of seriousness and commitment that will not produce any good result. The divisive forces are so strong that make intra-African trade highly insignificant. For example, Ghana and Cote d'Ivoire, though neighbors, with trade opportunities, have widely varying policies that undermine trade between them and hence affect the outcomes of their respective economic reform programs. In this case, while Ghana has followed a flexible exchange rate policy, partly related to relatively higher macroeconomic instability, Côte d'Ivoire has had a fixed exchange rate anchored to the French Franc. The inherent subsidy that the CFA franc enjoys as a result of its relationship with the French Franc (now with the Euro) effectively distorts the trading relationship between the two countries.

There are also besides marked differences in income and industrialization, the lack of political congeniality in foreign affairs among these countries, implying that neighboring countries are often on opposite sides of the cold war divide. Also prevalent is the very weak and reduced fiscal capacity and willingness among the member countries to provide compensation payments as seen clearly from the history of the African Development Bank and NEPAD.

There is the lack of political will and effective leadership which otherwise was the main propelling force behind the EU's success story. The absence of effective political leadership further accounted for the deficiencies in economic governance in Africa.

The implication of the above is that, despite several schemes and initiatives for creating integration zones in Africa, the continent continues to record comparatively the least proportion of intra-regional trade with only $12 \%$ of all its exports happening within Africa, as against that of $25 \%$ in ASEAN and over $60 \%$ in the European Union. [18 p1] The above state of affairs which prevails till date can further be explained from the following political and socio-economic points of view:

The first is the prevailing political crises and instability in many countries of Africa which situation takes much attention from national governments and even regional organizations to focus on such issues instead of economic growth and development matters. The implication is that the region's trade policies have mainly focused on local crisis rather than widening 
access to the developed economies. The few policies that are intra-Africa trade policies are scarcely paid attention to and so are not implemented. Part of this is that nations fear that opening their borders for economic and trade relations would rather encourage other movements like those of refugees, international criminals and rebels. To this extent, even the Africa Union seems to be preoccupied with political challenges in the continent and is unable to duly focus on economic issues of importance.

Another challenge to intra-African trade is poor and dilapidated infrastructure in the form of poor roads and railways within the region. These combine to make it very costly and difficult in the transportation of goods and human beings within the continent. Many of the busiest roads are unpaved. [19] For instance, in the SADC region the road which links South Africa, Zimbabwe, Zambia and Democratic Republic of Congo (DRC) is still in a dilapidated state and many routes pass through upheaval countries where basic maintenance is often abandoned. For instance at the heart of Africa in DRC, Central African Republic and Southern Sudan these countries link Southern part of Africa with the Northern part which makes regional integration a very big mountain to climb. It is also a fact that these countries above belong to different regional groupings with divergent loyalties that frustrate movement of goods and human beings across them.

In addition to the above stated are the very low level ICT infrastructures, energy and power crisis in the region which altogether make it very difficult to explore trade opportunities in the region. Till now the cost of ICT is high in the region and this contributes to hindering effective highspeed internet browsing and online shopping needed to enhance business, e-governance and other domestic uses. This however, is not to discountenance the progress that has been made around ICT as witnessed by access of cell phones for making calls and text messages though with limited access to internet especially in rural areas.

Other problems revolve around the "lenient or recognized", structure for regional trade, comprising of nontariff obstacles, restraining guidelines of origin, poor lawful and governing atmospheres and a lack of trade simplification to enable easy business activities. These have to be resolved for Africa to be competitive on the international market.

There are also the obstructive trade commitments made by African countries at the multilateral, regional and bilateral levels. These existing trade pacts with mainly developed countries often establish the granting of one-way trade preferences to reciprocal free trade agreements. For example, Economic Partnership Agreements with Europe; African Growth Opportunity Act with the US, the United States often has first extended unilateral trade preferences ( e.g. The Caribbean Basin Initiative and the Andean Trade Preferences Act) to its partner countries, and then negotiated so-called framework/agreements that establish consultative for bilateral trade relations and the settlement of disputes. [20]

The above has led to many countries splitting away from their Regional Economic Communities (RECs) with the main goal of advancing more than their counterparts.

\section{Conclusion and Recommendations}

\subsection{Conclusion}

Efforts towards creation of a continental free market have remained a constant factor among generations of leadership in Africa, but the results from such efforts have as well remained constantly far below expectations. In other words, there has not been a strong correlation between the relevant policy targets and the achievements afterward. A number of challenges, some of which are constant as well have impeded the successful establishment of Free Trade Area in Africa. Such challenges include: Lack of consistency in development of policies; political instability in many parts of the regions; as well as the overriding lack of commitment in the implementation of existing policies.

There are also the lingering dependence on similar export crops traded on intra-regionally by most African countries, marked differences in income and level of industrialization and lack of political congeniality in foreign affairs among these countries, implying that neighboring countries are often on opposite sides of the cold war divide. Also prevalent is the very weak and reduced fiscal capacity and willingness among the member countries to provide compensation payments as seen clearly from the history of the African Development Bank and NEPAD.

As pointed out earlier, there are also the obstructive trade commitments made by African countries at the multilateral, regional and bilateral level which often establish the granting of one-way trade preferences to reciprocal free trade agreements.

The way forward therefore is to intensify efforts towards eliminating duplicative membership and member states participation in other regional economic integration schemes that may compete with or undermine each other, to work out ways of strengthening the bloc's bargaining power when negotiating international deals.

\subsection{Recommendations}

In the new AU's CFTA energized drive towards the destination, this paper recommends that the new vigor of efforts be directed at the development of regional value chains; through fragmentation/ dividing different stages of production of particular goods to create new opportunities and ties that will eliminate the urge to compete against each other in all aspects. Again, minimising trade frictions such as delays in border clearance or low quality distribution facilities is necessary at this point. United Africa stands and divided she falls.

\section{References}

[1] O. N. Nwaodu. The African Union and the Question of Development in Africa, Owerri, Mega Atlas Ltd. 2010. 
[2] R. I. Onwuka. "The Anguish of Dependent Regionalism in Africa", Inaugural Lecture delivered at Obafemi Awolowo University, on January, 1988, Ile-Ife, Obafemi Awolowo Press Limited. 1991.

[3] E. O. C. Ijeoma and O. N. Nwaodu. Eds. Third World Development Strategies: Decades of Fascination and Frustration, Pretoria, 2013.

[4] E. B. Haas. The Uniting for Europe, Social and Economic Forces, 1950-1957, Stanford University Press.1968.

[5] J. Mapuva and Muyengwa-Mapuva. The SADC regional bloc: What challenges and prospects for regional integration, Cape Town, Law, Democracy \& Development. 2014.

[6] R. Leach. Europe: A concise Encyclopedia of the European Union. 4thed., London, Profiles Books Ltd. 2004:87.

[7] F. McDonald. Market Integration in the European Union, in McDonald, F. and Dearden S. (eds.), European Economic Integration, England, Pearson Educational Limited.1999.

[8] I. Mclean and A. Macmillan, (Eds,) The Concise Oxford Dictionary of Politics, Oxford University Press.2003.

[9] African Union. Southern African Development Community (SADC), Addis Ababa, the African Union Commission, accessedon18, October, 2017, www.sadc.int.2011.

[10] C. O. Lercheand A. A. Said. Concepts of International Politics in Global Perspective 3rded. Prentice-HallInc, Eaglewood Cliff. 1979.

[11] African Union. Third Meeting of the African Facility Joint Coordination Committee, Joint Communiqué, African Union Commission, Addis Ababa, 2006.
[12] K, Mammo \& P, Draper. "South African international trade diplomacy: Implications for regional integration" at 37.2006.

[13] Tralac."Memberships in multiple regional trading agreements: Legal implications for the conduct of trade negotiations" (2003) Tralac. 2017. Available at www.tralac.org/scripts/contnent.php?=1914

[14] Mail \& Guardian Online Network: (In a separate analysis of the extant situation,12 June, 2012.

[15] S. K. Tadelle. The Role of Civil Society in African Regional Integration. 2016. Accessed on 24 March 2017 at: https://www.linkedin.com/pulse/role-civil-society-africanregional-integration-seife-tadelle-hon-

[16] T. Hartzenberg. Staff Working Paper, ERSD-2011-14.2011. Regional integration in Africa. 2011.

[17] United Nations. Assessing Regional Integration in Africa V: Towards an African Continental Free Trade Area. UNECA. Org Publications. 2010.

[18] C. K. Regional Integration is a must for Africa. Kenya Reuters: World Economic Forum. 2013.

[19] M. Retting, A. W. Kamau, and A. S. Muluvi. The African Union Can Do More to Support Regional Integration. Washington DC: The Brooking Institution. 2013.

[20] Schott. Korea-U.S Free Trade Revisited. Peterson institute for International Economics. 2001. 